\title{
Post Challenging Serum Cytokine Profile (Th1 \& Th2) in the Vaccinated Mice (Balb/C) With a New Formulation of Leishmania major Antigen
}

\author{
Leishmania major Antijeninin Yeni Bir Formülasyonu ile Aşılanmış Farelerde (Balb/C) \\ Antijen ile Karşılaşma Sonrası Serum Sitokin Profili (Th1 ve Th2)
}

\begin{abstract}
Afshineh Latifynia', Ali Khamisipour², Mohammad Javad Gharagozlou³, Said Bokaie ${ }^{4}$ Mohammad Vodjgani', Zahra Gheflati ${ }^{1}$, Marzieh Mosavi ${ }^{5}$, Nematollah Khansari ${ }^{1}$

'Department of Immununology, Faculty of Medicine, Tehran University of Medical Sciences, Tehran, Islamic Republic of Iran ${ }^{2}$ Department of Leprosy and Dermal Disease Center, Tehran University of Medical Sciences, Tehran, Islamic Republic of Iran ${ }^{3}$ Department of Pathobiology, Veterinary Medicine, University of Tehran, Islamic Republic of Iran ${ }^{4}$ Department of Epidemiology, Veterinary Medicine, University of Tehran, Islamic Republic of Iran ${ }^{5}$ Faculty of Medicine, Tehran University of Medical Sciences, Tehran, Islamic Republic of Iran
\end{abstract}

\section{ABSTRACT}

Objective: The aim of this study was to carry out experiments further to our previous new formulation to modify the Leishmania major antigen that had satisfactory results previously.

Methods: In this study we made a preliminary, new vaccine with the same methodology and selected two injection doses (100\&200 $\mu \mathrm{g} / 0.1 \mathrm{~mL})$, three injection Groups: Leishmania plus BCG (LB), Leishmania plus new adjuvant (Teucrium Polium) [LT], Leishmania plus BCG and Teucrium Polium (LBT), and one susceptible mouse Group (Balb/c) and measure two types of cytokines: Th1 (IFN- $\gamma$, IL-12) and Th2 (IL-4, IL-10) We prepared crude antigen combinations by five different methods using antigens from $L$. major parasites. Phase I was done in the animal model. In our study, Leishmania antigen was examined both with BCG and the new adjuvant (TP) in three Groups in two injection doses (100.200 $\mu \mathrm{g} / 1 \mathrm{~mL})$ and Balb/c mice.

Results: Our results showed that in three injection Groups (LB, LT and LBT) that received each or both BCG and TP as adjutant with injection doses of 100 and $200 \mu \mathrm{g} / 1 \mathrm{~mL}$ with two booster doses: the LBT Group had the lowest IFN $\gamma$ and highest IL-12 value, LT and LB Groups have equal IL-12, but LB have more IFN $\gamma$ and IL-10 but less than IL-4 in the LT Group.

Conclusion: In this study, the LBT Group has statistical differences regarding IL-12 and IL-10 from the other Groups.

(Turkiye Parazitol Derg 2013; 37: 233-40)

Key Words: Leishmania major antigen, cytokine, IL-4, IL-10, IL-12, IFN $\gamma$, challenge

Received: 26.11.2012

Accepted: 16.09 .2013

\section{ÖZET}

Amaç: Bu çalışmanın amacı, daha önce tatmin edici sonuçlar vermiş olan Leishmania major antijenini modifiye etmek için önceki yeni formülasyonumuzu daha fazla deney yaparak ileri taşımaktır.

Yöntemler: Bu çalışmada aynı metodoloji ile öncül yeni bir aşı yaptık ve şunları seçtik; iki enjeksiyon dozu (100 ve 200 ㅆg/o.1 mL), üç enjeksiyon grubu: Leishmania artı BCG (LB), Leishmania artı yeni adjuvan (Teucrium polium) (LT), Leishmania artı BCG ve Teucrium polium (LBT) ve bir duyarlı bir fare grubu (Balb/c) ve iki tip sitokin ölçümü: Th1 (IFN-, IL-12) ve Th2 (IL-4, IL-10). L. major parazitlerinin antijenlerini kullanarak beş farklı metotla ham antijen kombinasyonları hazırladık. Hayvan modelinde Faz I yapıldı. Çalışmamızda Leishmania antijeni; hem BCG hem de yeni adjuvan (TP) ile üç grupta, iki enjeksiyon dozunda (100, $200 \mu \mathrm{g} / 1 \mathrm{~mL})$ ve Balb/c farelerinde incelendi.

Address for Correspondence / Yazışma Adresi: Afshineh Latifynia, MSc, Mphil, PhD student Department of Immununology, Faculty of Medicine, Tehran University of Medical Sciences, Tehran, Islamic Republic of Iran. Phone: +9821 66439463 E-mail: swt_f@yahoo.com doi:10.5152/tpd.2013.2988 
Bulgular: Sonuçlarımız gösterdi ki, iki güçlendirici dozda 100 ve $200 \mu \mathrm{g} / 1$ mL enjeksiyon dozları ile adjuvan olarak BCG ve TP'nin birini veya ikisini alan üç enjeksiyon grubunda (LB, LT ve LBT): LBT grubu en düşük IFNy ve en yüksek IL-12 değerine sahipti, LT ve LB grupları aynı IL-12 düzeyine sahipti, ancak LB, LT grubundan daha çok IFNy ve IL-10, daha az IL-4'e sahipti.

Sonuç: Bu çalışmada, LBT grubu IL-12 ve IL-10 açısından diğer gruplardan istatistiksel farklılıklara sahiptir. (Turkiye Parazitol Derg 2013; 37: 233-40)

Anahtar Sözcükler: Leishmania major antijen, sitokin, IL-4, IL-10, IL-12, IFNy, karşılaşma

\section{INTRODUCTION}

Leishmania is caused by the protozoan parasites Leishmania species that are transmitted by the bite of phlebotomia sand flies. In vertebrate hosts, Leishmania survive and multiply as non-motile amastigotes, primarily in macrophages. The genus Leishmania comprises 30 species, of which about 20 are pathogenic for humans (1). For most species, humans are accidental hosts since Leishmania is primarily a zoonotic disease or has recent zoonotic forms of disease in areas not considered previously to be endemic (2). Up to now, successful vaccination strategy against Leishmaniasis has been limited to cutaneous Leishmania with small doses of living virulent L. major promastigotes as a selected site (3). Although mouse models have been used for the study of both cutaneous and visceral Leishmaniasis, they more closely reflect the human cutaneous Leishmaniasis than visceral disease. Up to now, several vaccine formulations that demonstrated efficiency in the mouse models, were not protective in primates $(4,5)$. This underscores the need for new methods to assess the immune response of animals to vaccination that can better predict the response to virulent organism challenge in primates and humans. New methods would be useful for the detection of parasites as well as assessment of pathology. Effective diagnosis of the progression of infection with a candidate vaccine will require assessment of the genetic stability of the agent. Results obtained from the mouse model, although practical and informative, must be further confirmed in a primate model that more closely predicts pathogenesis and immunogenesis in humans (6). A constraint of this proposed unorthodox alternative is that it relies preliminarily on the unique Th1/Th2 paradigm of the mouse model of Leishmaniasis. In other words, offsetting the parasite's Th2 strategies instead of fostering the Th1 response that is elicited during infection can be an efficient alternative in vaccine development against Leishmaniasis (7).

To date, two host systems have been classified for studying Leishmania infection on the basis of susceptibility and resistance of the host. This observation extends to the murine L. major model, where the strain of inbred mouse determines the outcome of infection, $\mathrm{C} 57 \mathrm{BL} / 6$ mice being uniformly resistant and BALB/c consistently susceptible (8). Dendritic cells (DCs) are potent antigen presenting cells and can induce $T$ cell activation efficiently (9). It has been also shown that DCs are the source of different cytokines such as IL-12, IL-10, and IFN- $\gamma$ (10-12). Incubation of Leishmania promastigotes with dendritic cells induced early IL-12 production in vitro, which might have originated from the pre existing pool of IL-12 p70 which was secreted soon after ligation of any microbial product (13), suggesting the role of DCs in the initiation of $\mathrm{T}$ cell immune response in Leishmania infection. It is also reported that uptake of Leishmania amastigotes by skin derived DCs induce IL-12 p70, upregulates costimulatory molecules and vaccinates against Leishmania major infection. In marked contrast, L. major inhibits IL-12 production in macrophages $(14,15)$.

IL-10 appears to constitute a major regulatory control in the outcome of infection. Failure to produce IL-12 has similarly been associated with the active form of the disease (16).

T cell-cloning strategy can be easily adapted for the detection of IL-10-inducing antigens. The protection induced by LPG2- parasites is basically not associated with enhanced IFN- $\gamma$ production in response to Leishmania antigens, but clearly with a dramatic suppression of IL-4 and IL-10 responses to the same antigens. As already mentioned, recent evidence suggests that Leishmania antigens stimulate $T$ regulating cells $(C D 4+C D 25+)$, thus impairing the activation of the effecter CD4+CD25-t cells (7). It is well documented that Th1 immune response is the key event in preventing Leishmania infection. Activated Th1 cells induce IFN- $\gamma$ that in turn activates the macrophages which kill the parasites. C57BL/6 mice mount an early Th1 immune response and prevent the further growth of the parasite causing a self-healing phenotype $(17,18)$. In contrast, the susceptible BALB/c strain mounts early Th2 response and this results in a nonhealing lesion and exaggeration of the disease $(17,19,20)$. Our previous findings on the same new formulation antigen in two Groups of mice: (susceptible/Balb/c) and (resistance/conventional), have shown that it produced positive DTH (21), increasing in white pulp size (22), which had significant differences and correlation that depended on doses, mice Groups, and injection Groups (23). Neutralization of IL-12 during infection make resistant mice susceptible to Leishmania infection (24). Another report suggested that reconstitution of IL-12 P40-/- mice with exogenous IL-12 initiates the Th1 response and protects the mice (25).These observations suggested the critical and decisive role of endogenous IL-12 in Leishmaniasis (26). The capacity of exogenous IL-12 to heal infected Balb/c mice correlated with the powerful effect of IL-12 in suppressing IL-4 transcription and protein production (27). It is now known that IL-10 plays a role in disease progression, but whether with IL-4 or prior to the IL-4 phase is not known (28). These findings explain our previous suggestion about cytokine patterns which increase Th1 cytokines amounts such as IL-12 and IFN- $\gamma$, cause high positive DTH response, and conversly, Th2 cytokines like IL-4, IL-10 level enhancement in low DTH response to cutaneous Leishmania disease (21). Moreover, IL-4 and IL-10 act together in the presence of exacerbated antigens (29). Hence, it would appear that IL-10 may be the most appropriate cytokine to serve as an indicator of failure or success of vaccination. Another essential requirement seems to be IL-12 which is a critical cytokine in the initiation and maintenance of immunity, as well as a very effective adjuvant (30). When L. major causes a 
single cutaneous lesion, or undergoes spontaneous cure, the subject is resistant and probably infection is inhibited in macrophages via innate immunity and production of interferon gamma and $\mathrm{IL}_{12}$ by a $\mathrm{Th}_{1}$ response that leads to parasite killing, and probably in any future challenge, the subject is immune (26). The effect of BCG on the course of established murine Leishmaniasis was examined previously. Although to date there is no vaccine against Leishmania, several of the vaccine preparations are in advanced stages of clinical testing. Many different methods of vaccine preparation plus or without adjutant were used. We prepared crude antigen combinations by five different methods using antigens from L. major parasites. Phase 1 was carried out in an animal model. In our study, the Leishmania antigen was examined both with BCG and new adjuvant (T.P) in three injection Groups (LB, LT and LBT) and two injection doses (100, 200 $\mu \mathrm{g} / 1 \mathrm{~mL}$ ) and Balb/c mice. In these injected Groups Th1 (IFN $\gamma$, IL-12) and Th2 cytokines (IL-4, IL-10) were measured. Our results showed that in the three injection Groups (LB, LT and LBT) that received either or both $B C G$ and $T P$ as adjutant with injection doses 100, $200 \mu \mathrm{g} / 1 \mathrm{~mL}$ with two booster doses, the LBT Group has lowest the IFN $\gamma$ and highest IL-12 value, LT and LB Groups have equal IL-12, but LB have more IFN $\gamma$ and IL-10 but less than IL-4 in the LT Group.

\section{METHODS}

This study was done in compliance with the Helsinki Declaration, and the protocol was approved by the Research Deputy of Tehran University of Medical Sciences, Tehran, Iran. For detail procedures please refer to Latiynia, et al (21-23). In brief Balb/c mice $(n=120)$ were obtained at three months old.

\section{Culture and Isolation of Leishmania Parasites:}

Leishmania parasites and antigens from promastigotes of L. major (WHO) strain were kindly provided by the Tehran University of Medical Sciences and were grown in NNN medium (14 gr bactopeptone, $6 \mathrm{gr} \mathrm{Nacl}$, Rabbit blood $300 \mathrm{~mL}$ and up to $1200 \mathrm{~mL} \mathrm{H}_{2} \mathrm{O}_{2}$ ) and the second step were grown in RPMI 1640 culture, both FCS5\% and 10\%. Harvested parasites were washed three times with normal saline solution $(0.9 \%)$ or phosphate buffer saline (PBS). The parasite were counted in a neubar chamber and then kept at $-700 \mathrm{c}$ until use. After parasite accumulation in one flask, it was diluted to a concentration of 5.92. 10 ${ }^{10}$.

\section{Vaccine Preparation}

Each vaccine was then certified according to 100 or $200 \mu \mathrm{g} / 0.1$ $\mathrm{mL}$ Leishmania protein per one dose. The content of protein in each dose was estimated by the Lowry method (31). The vaccine was stored at 40C until use. Just before injection BCG Vaccine "SSI" (Mycobacterium bovis, Bacillus Calmette Gurine, BCG Strain, Pasteur Institute of Iran Frozen - dried BCG Vaccine Pasteur France. 1173 P2 Secondary seed lot C. batch No.179.Feb.1995) was suspended in a diluted solution of SSI solvent $\left(125 \mathrm{mg} \mathrm{Mg} \mathrm{SO}{ }_{4}, 125 \mathrm{mg} \mathrm{K} 2 \mathrm{PO}_{4}, 1 \mathrm{mg}\right.$ Laspargine, $\mathrm{H}_{2} \mathrm{O}$, $12.5 \mathrm{mg}$ iron ammonium citrate, $18.4 \mathrm{mg} 85 \%$ glycerol, $0.5 \mathrm{mg}$ citric acid, H2O $1 \mathrm{~mL}$ for injection/manufacturer's insert) and the amount of BCG for each injection was $2 \times 10^{2.3}$ unit/0.1 mL of injection dose and $400 \mathrm{mg}$ teucrium polium (32) dissolved in $1 \mathrm{~mL}$ distilled water and $2.5 \mathrm{mg} / 0.1 \mathrm{~mL}$ used for each injection dosage solution $(100,200 \mu \mathrm{g} / \mathrm{mL})$.
We have three injection groups: 1-LT (Leishmania plus teucrium as adjuvant), 2-LB (Leishmania plus BCG as adjuvant) and 3-LBT (Leishmania plus BCG and plus Teucrium): and each other received two injection doses $(100,200) \mu \mathrm{g} / 1 \mathrm{~mL}$ protein, of Leishmania antigen and received the first booster dose after one week and the second booster dose after two weeks. Leishmania parasites and antigens from promastigotes of L. major (WHO) strain) were kindly provided by the Tehran University of Medical Sciences and were grown in an NNN medium (14 gr bactopeptone, $6 \mathrm{gr} \mathrm{Nacl}$, Rabbit blood $300 \mathrm{~mL}$ and up to $1200 \mathrm{~mL} \mathrm{H}_{2} \mathrm{O}_{2}$ ) and the second step were grown in RPMI 1640 culture, both FCS5\% and 10\%. Harvested parasites were washed three times with normal saline solution $(0.9 \%)$ or phosphate buffer saline (PBS). The parasites were counted in a neubar chamber and then kept at -700c until use. After parasite accumulation in one flask, it was diluted to a concentration of $5.92 \times 10^{10}$. After parasite dilution, it was divided to 5 batches those each other used one procedure contains: freeze and thaw, autoclave, or $56^{\circ} \mathrm{C}$, and at least antigen were processing (21-23).Then, each vaccine was certified according to 100 or $200 \mu \mathrm{g} / 0.1 \mathrm{~mL}$ Leishmania protein per dose. The content of protein in each dose was estimated by the Lowry method (31). The vaccine was stored at $40 \mathrm{C}$ until use. Just before injection, BCG Vaccine "SSI" (Mycobacterium bovis, Bacillus Calmette Gurine, BCG Strain, Pasteur Institute of Iran Frozen-dried BCG Vaccine Pasteur France. 1173 P2 secondary seed lot C. batch No.179.Feb.1995) was suspended in a diluted solution of $\mathrm{SSI}$ solvent (125 mg Mg SO${ }_{4}, 125 \mathrm{mg} \mathrm{K}{ }_{2} \mathrm{PO} 4,1 \mathrm{mg}$ Laspargine, $\mathrm{H}_{2} \mathrm{O}, 12.5 \mathrm{mg}$ iron ammonium citrate, $18.4 \mathrm{mg} 85 \%$ glycerol, $0.5 \mathrm{mg}$ citric acid, $\mathrm{H}_{2} \mathrm{O} 1 \mathrm{~mL}$ for injection/manufacturer's insert) and the amount of BCG for each injection was $2 \times 10^{2.3}$ unit/0.1 mL of injection dose and $400 \mathrm{mg}$ teucrium polium (32) dissolved in $1 \mathrm{~mL}$ distilled water and $2.5 \mathrm{mg} / 0.1 \mathrm{~mL}$ of used for each injection dosage solution (100, $200 \mu \mathrm{g} / \mathrm{mL})$. After increasing two adjutants to Leishmania antigen solutions mentioned previously, two injection doses $(100,200 \mu \mathrm{g} / \mathrm{mL})$ were prepared.

\section{Vaccine Injection}

All doses were injected intra dermally into the tails in susceptible Balb/c mice both male and female in three injection groups: LT [Leishmania antigen doses (100, $200 \mu \mathrm{g} / 0.1 \mathrm{~mL}$ ) accompanied byteucrium polium as adjuvant], LB [Leishmania antigen doses $(100,200 \mu \mathrm{g} / 0.1 \mathrm{~mL})$ accompanied by BCG and teucrium polium as adjuvant], LBT [Leishmania antigen doses $(100,200 \mu \mathrm{g} / \mathrm{mL}$ ) accompanied by BCG and teucrium polium as adjuvant]. After the first injection we have two booster doses with an interval of one week. Twenty days after the third Leishmania injection or second booster dose, the mouse was challenged with 300000 live L. major. The protective response was evaluated by the challenge effects which were observed almost daily for 70 days in all mice. Evaluation included: inducing lesion, and survival and another critical signals. After this time the live mice were euthanized, and their serum used for cytokine levels and their level estimated with measurement of cytokine production by Enzyme Linked Immunosorbent Assay (ELISA).

Levels of IL-4, IL-10, IL-12, and IFN- $\gamma$ in the three injection groups and normal group were determined by sandwich ELISA, according to the recommendations of the manufacturer. Mice serum levels of IL-4, IL-10, IL-12 and IFN- $\gamma$ in the 
subjects measured by ELISA, using an automated micro plate reader, set at $405 \mathrm{~nm}$. The sensitivity limit was $20 \mathrm{pq} / \mathrm{mL}$ for IL-4, IL-10, and IFN- $\gamma$.

\section{RESULTS}

\section{Th1, Th2 Cytokine Profile to Induce Protective Immunity} In the first set of experiments, we compared the immune response induced by a new formulation of Leishmania major antigen which was injected in three injection groups: LT, LBand

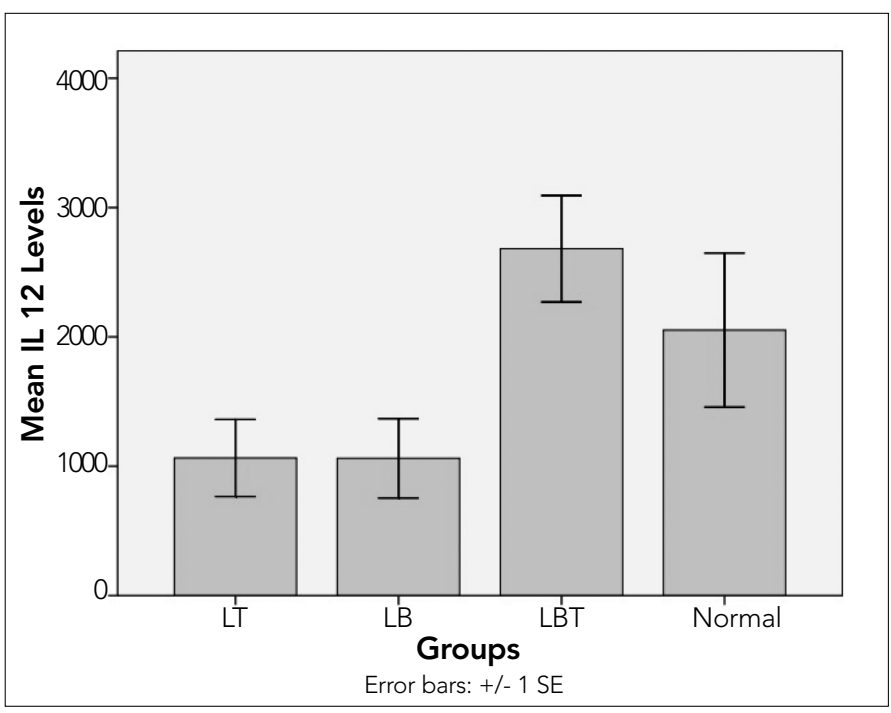

Figure 1. Mean of IL-12 level for three injection groups: LT, LB, LBT and normal group in serum of BalB./c mice. After challenge with live Leishmania major

LB: Leishmania plus BCG; LT: Leishmania plus new adjuvant (Teucrium Polium); LBT: Leishmania plus BCG and Teucrium Polium
LBT that each received two injection doses of antigen (100, 200) $\mu \mathrm{g} / 0.1 \mathrm{~mL}$ protein, andreceived two booster doses. With consideration to Th1 (IFN $\gamma$, IL-12) and Th2 (IL-10, IL-4) cytokine was determined as the following levels:

IL-12: Highest II-12 (2305.5 pg/mL) related to the LBT group and lowest IL-12 (1032and $1037 \mathrm{pg} / \mathrm{mL})$ was related to the $\mathrm{LT}$ and LB groups which have almost equal levels, but they are lower than the normal level (Figure 1). IL-12 and also IL-12 was higher in female (2091 pg/mL) than male mice $(611.08 \mathrm{pg} / \mathrm{mL})$. Correlation was significant at the 0.05 level with two tailed analysis $(p<0.005)$ (Table 1). Correlation between three injections and normal groups, considering IL-12 and Multiple Comparisons of IL-12 with Tukey Honestly Significant Difference Tukey (HSD) and 95\% Confidence Interval

Table 1. Correlation between IL-10 and IL-12 doses of 100 and $200 \mu \mathrm{g} / 0.1 \mathrm{~mL}$ combined. Pearson Correlation with 2 - tailed test show that IL-2 and IL-10 are inversely relatedand when IL-12 is increased II-10 is decreased. Correlation is significant at the 0.05 level (2-tailed)

\begin{tabular}{|c|c|c|c|}
\hline \multicolumn{4}{|c|}{ Correlations } \\
\hline & & IL12 Levels & IL10 Levels \\
\hline \multirow[t]{3}{*}{ IL12 Levels } & Pearson Correlation & 1 & $-.342^{\star}$ \\
\hline & Sig. (2-tailed) & & .041 \\
\hline & $\mathrm{N}$ & 36 & 36 \\
\hline \multirow[t]{3}{*}{ IL10 Levels } & Pearson Correlation & $-.342^{\star}$ & 1 \\
\hline & Sig. (2-tailed) & .041 & \\
\hline & $\mathrm{N}$ & 36 & 36 \\
\hline
\end{tabular}

Table 2. Correlation between three injection and normal groups, considering IL-12 and Multiple Comparisons of IL-12 with Tukey HSD and 95\% Confidence Interval show that the mean difference is significant at the 0.05 level

\begin{tabular}{|c|c|c|c|c|c|c|}
\hline \multicolumn{7}{|c|}{ Multiple Comparisons } \\
\hline \multicolumn{7}{|c|}{ IL12 Levels Tukey HSD } \\
\hline (I) Groups & (J) Groups & Mean Difference (I-J) & Std. Error & Sig. & \multicolumn{2}{|c|}{ 95\% Confidence Interval } \\
\hline \multirow[t]{2}{*}{ LT } & LB & 2.669 & 463.753 & 1.000 & -1253.81 & 1259.14 \\
\hline & LBT & $-1617.481^{\star}$ & 495.436 & .013 & -2959.80 & -275.17 \\
\hline \multirow[t]{3}{*}{ LB } & $\mathrm{LT}$ & -2.669 & 463.753 & 1.000 & -1259.14 & 1253.81 \\
\hline & LBT & $-1620.150 *$ & 522.981 & .020 & -3037.09 & -203.21 \\
\hline & Normal & -991.300 & 603.886 & .371 & -2627.45 & 644.85 \\
\hline \multirow[t]{2}{*}{ LBT } & LT & $1617.481^{*}$ & 495.436 & .013 & 275.17 & 2959.80 \\
\hline & LB & $1620.150^{\star}$ & 522.981 & .020 & 203.21 & 3037.09 \\
\hline \multirow{2}{*}{ Normal } & LB & 991.300 & 603.886 & .371 & -644.85 & 2627.45 \\
\hline & LBT & -628.850 & 628.545 & .750 & -2331.80 & 1074.10 \\
\hline
\end{tabular}


Table 3. Correlation between injection groups and Th1 cytokines (IL-12, IFN- $\gamma$ ) and Th2 cytokines (IL-4, IL-10) Doses 100 and $200 \mu \mathrm{g} / 0.1 \mathrm{~mL}$ combined

\begin{tabular}{|c|c|c|c|c|c|c|}
\hline \multicolumn{7}{|l|}{ ANOVA } \\
\hline & & Sum of Squares & $d f$ & Mean Square & $F$ & Sig. \\
\hline \multirow[t]{2}{*}{ Gamma IFN Levels } & Between Groups & 98.548 & 3 & 32.849 & .812 & .497 \\
\hline & Total & 1393.583 & 35 & & & \\
\hline \multirow[t]{2}{*}{ IL4 Levels } & Between Groups & 487.502 & 3 & 162.501 & 1.207 & .323 \\
\hline & Total & 4795.586 & 35 & & & \\
\hline \multirow[t]{3}{*}{ IL10 Levels } & Between Groups & 263.395 & 3 & 87.798 & 1.553 & .220 \\
\hline & Within Groups & 1809.174 & 32 & 56.537 & & \\
\hline & Total & 2072.569 & 35 & & & \\
\hline IL12 Levels & Between Groups & 1.696E7 & 3 & 5653365.438 & 4.651 & .008 \\
\hline
\end{tabular}

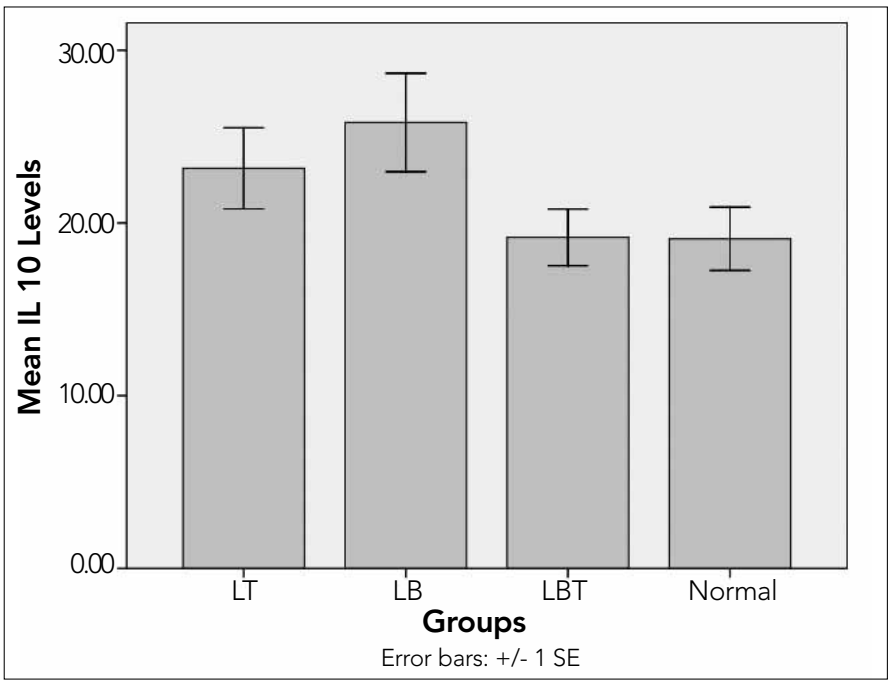

Figure 2. Mean of IL-10 level for three injection groups: LT, LB, LBT and normal group in serum of BalB./c mice. After challenge with live Leishmania major

LB: Leishmania plus BCG; LT: Leishmania plus new adjuvant (Teucrium Polium); LBT: Leishmania plus BCG and teucrium polium

show that the mean difference is significant at the 0.05 level. $(p<0.005)$ (Table 2). Correlation between injection groups and Th1 cytokines (IL-12, IFN- $\gamma$ ) and Th2 cytokines (IL-4, IL-10) doses of 100 and $200 \mu \mathrm{g} / 0.1 \mathrm{~mL}$ combined. The ANOVA test shows that means square of IL-12 between groups and compared to other Th1, Th2 cytokines is significant. $(p<0.005)$ (Table 3$)$. Pearson Correlation with the 2 - tailed test shows that IL-2 and IL-10 are inversely related and when IL-12 is increased II-10 decreased and also decrease of IL-12 occurs with increasing of IL-10.

IL-10: Highest IL-10 (27.2 pg/mL) was related to LB and lowest concentration related to LBT group $(19.39 \mathrm{pg} / \mathrm{mL})$. This is almost equal to the normal group's level, but the LT group's level is

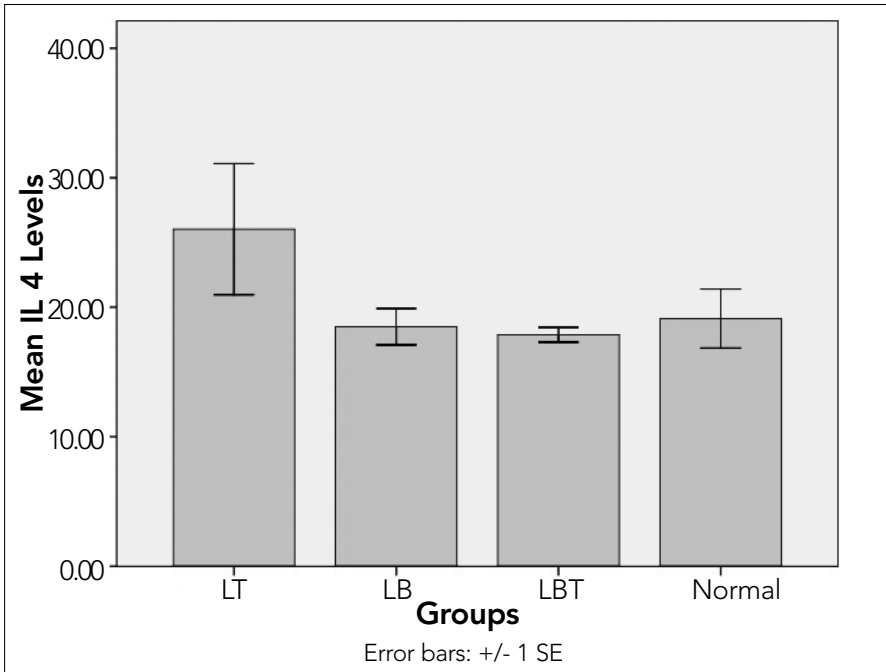

Figure 3. Mean of IL-4 level for three injection groups: LT, LB, LBT and normal group in serum of BalB./c mice. After challenge with live Leishmania major

LB: Leishmania plus BCG; LT: Leishmania plus new adjuvant (Teucrium Polium); LBT: Leishmania plus BCG and teucrium polium

higher than the LBT group and also lower than the LB group (Figure 2). IL-10 in male (25.27 pg/mL) is higher than female mice (23.67 pg/mL). Correlation between IL-10 and IL-12 doses 100 and $200 \mu \mathrm{g} / 0.1 \mathrm{~mL}$ combined. Pearson Correlation with the 2-tailed test shows that IL-2 and IL-are inversely related and when IL-10 is increased, II-12 decreased but decline of IL-10 is accompanied byincrease of IL-12. Correlation is significant at the 0.05 level with 2-tailed analysis $(p<0.005)$ (Table 1).

IL-4: Highest IL-4 (25.52 pg/mL) related to the LT and lowest IL-4 ((17.52 pg/mL) related to the LBT and LB groups. These two groups not only are equal, but also equal to the normal group. (Figure 3). IL-4 in male (23.99 pg/mL) is higher than female mice 


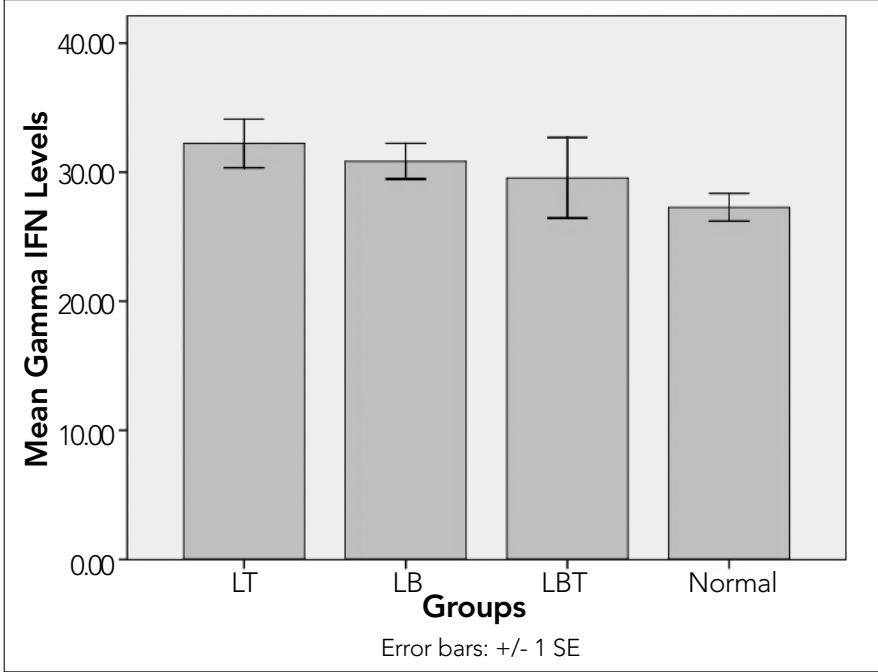

Figure 4. Mean of IFN- $\gamma$ level for three injection groups: LT, LB, LBT and normal group in serum of BalB./c mice. After challenge with live Leishmania major

LB: Leishmania plus BCG; LT: Leishmania plus new adjuvant (Teucrium Polium); LBT: Leishmania plus BCG and teucrium polium

(21.7 pg/mL). IL-4 is not significant at the 0.05 level (2-tailed) (Table 1). Correlation between injection groups and Th1 cytokines (IL-12, IFN- $\gamma$ ) and Th2 cytokines (IL-4, IL-10) doses of 100 and $200 \mu \mathrm{g} / 0.1 \mathrm{~mL}$ combined. ANOVA test show that means square of IL-4 between groups and compared to the other Th1, Th2 cytokines is not significant (Table 3 ).

IFN $\gamma$ in the LB group has the highest level (35.4 piqogram $/ \mathrm{mL}$ )) $(27.2 \mathrm{pg} / \mathrm{mL})$ related to the $\mathrm{LT}$ and lowest concentration related to the LBT group (19.39 $\mathrm{pg} / \mathrm{mL}$ ) (Figure 4). IFN $\gamma$ is higher in male (32 pg/mL) than female mice $(26.23 \mathrm{pg} / \mathrm{mL})$. IFN- $\gamma$ is not significant at the 0.05 level (2-tailed) (Table 1). Correlation between injection groups and Th1 cytokines (IL-12, IFN- $\gamma$ ) and Th2 cytokines (IL-4, IL-10) doses of 100 and $200 \mu \mathrm{g} / 0.1 \mathrm{~mL}$ combined. Correlation between three injection and normal groups', considering IL-12 and Multiple Comparisons of IL-12 with Tukey HSD and $95 \%$ Confidence Interval, show that the mean difference is significant at the 0.05 level (Table 2). ANOVA test show that means square of IFN $\gamma$ between groups and compared to the other Th1, Th2 cytokines is not significant (Table 3). The Effect of Three Injection Groups: (LB, LT and LBT) on
New Formulation of Leishmania Major Antigen.

LBT Group: has the lowest IFN $\gamma$, IL-10, IL-4 and highest IL-12. IL-12 in LBT group post challenge (Table 2).

LT Group: has the highest IL-4, almost equal IL-12 with LB group, but IFN $\gamma$ and IL-10 is lower than the LB group. Correlation between three injection and normal groups', considering IL-12 and Multiple Comparisons of IL-12 with Tukey HSD and 95\% Confidence Intervalshows that the mean difference is not significant at the 0.05 level (Table 2).

LB Group: has the highest IL-10 and IFN $\gamma$, but IL-12 is almost equal to the LT group and IL- 4 is more than the LBT but less than the LT Groups. Correlation between three injection and normal groups', considering IL-12 and Multiple Comparisons of IL-12 with Tukey HSD and 95\% Confidence Interval shows that the mean difference is not significant at the 0.05 level (Table 2).

In this present study, there was a significant difference between the sexes in mice regarding their survival after 70 days. Almost all of the female mice (19 subjects) were living and killed after that time, while only 13 male mice died after this time and others had not survived. Notice thatwe found (IFN- $\gamma$ IL-10, IL-4) increased not only in female mice but also higher than all normal mice but, more important is that another Th1 cytokine (IL-12) in male mice is very low, but in females it is very high. For statistical analysis both doses, $100 \& 200 \mu \mathrm{g} / \mathrm{mL}$ were considered as one injection dose.

\section{DISCUSSION}

Cytokines play an important role in the cutaneous form of Leishmania disease. Its results in formation of skin ulcers at the site of the face, neck, arms and legs. The pathology of Leishmania infection is determined not only by the parasite species, but also by host genetics and immune factors. Most of the experimental immunological data come from mouse models and less is known about the immunology of human Leishmaniasis. In the case of cutaneous Leishmaniasis, effective protection against infection has been largely attributed to the development of a potent CD4+Th1 type immune response, characterized by the production of IL-12 and IFN- $\gamma$, which subsequently mediates macrophage activation, nitric oxide production and parasite killing. With regard to this, we decided to study three injection groups (LB, LT, LBT) that received a new formulation of Leishmania major antigen and both Teucrium and BCG as adjuvant together or alone. All three groups used two injection doses $(100,200)$ $\mu \mathrm{g} / 0.1 \mathrm{~mL}$ of antigen protein.

This study IL-10 had significant differences with other cytokines and had the lowest level in the LBT injection group, while LT and LB injection groups had similar levels of IL-12 which were higher than the LBT group. In contrast, IL-12, which also had significant differences with other cytokines, had the highest level in the LBT group, but LB and LT groups had similar levels for IL-12 and were lower than the LBT group (Table 1, 2). This finding, confirmed by previous studies suggested that IL-10 and IL-12 have inverse roles in the progress of disease.

Susceptible BALB/c strain mouse produce early Th2 response which results in a non healing lesion and exaggeration of disease $(17,19,20)$. In our previous findings on the same new formulation antigen in two groups of mice: Balb/c and (resistance/conventional), produced positive DTH (21), increasing in white pulp size (22). In recent studies: neutralization of IL-12 during infection make resistant mice susceptible to Leshmania infection (24) and suggested that reconstitution of IL-12 P40-/- mice with exogenous IL-12 initiates the Th1 response and protects the mice (25). These observations suggested the critical and decisive role of endogenous IL-12 in Leishmaniasis (26), and the capacity of exogenous IL-12 to heal infected Balb/c mice correlated with the powerful effect of IL-12 in suppressing IL-4 transcription and protein production (27). It is now known that IL-10 plays a role in disease progression, but whether with IL-4 or prior to the IL-4 phase is not known (28). This explains our previous suggestion 
regarding cytokine patterns about the increase of Th1 cytokines amounts such as IL-12 and IFN- $\gamma$ and production of a high positive DTH response, and Th2 cytokines like IL-4, IL-10 levels induce low DTH in cutaneous Leishmania disease (21). Several studies have demonstrated that IL-4 and IL-10 act together in the presence of exacerbated antigens (29), and it appears that IL-10 may be the most appropriate cytokine to serve as an indicator of failure or success of vaccination. Another essential requirement seems to be IL-12, which is a critical cytokine in the initiation and maintenance of immunity, as well as a very effective adjuvant (30). When L. major causes a single cutaneous lesion, or undergoes spontaneous cure, the subject is resistant, and probably infection is inhibited in macrophages via an innate immunity and production of interferon gamma and IL12 by Th response that leads to parasite killing, and probably in any future challenge, the subject is immune (2). Leishmaniasis in general, particularly cutaneous Leishmaniasis, is probably one of a few parasitic diseases that is most likely to be controlled by vaccines. In the author's recent research, the hypothesis proposes that the greatest increase in spleen white pulp size expansion in mice may be related to IL-4 and IL-10 production, resulting in humeral immune responses. Both IL4-and IL-10 are associated with systemic disease without long term immunity to cutaneous Leishmaniasis. Our previous results suggested that in type I mice (susceptible) in injection Group 3: included Leishmania antigen plus BCG and booster dose of antigen at doses of $400-500 \mu \mathrm{g} / \mathrm{mL}$ which had low DTH response, could produce IL-4 or IL-10. SWP expansion is related to the production of cell mediated immune responses, IFN- $\gamma$ and (most likely) IL-4 suppression, which may lead to long term immunity to cutaneous Leishmaniasis. Our results are similar to our previous findings in mice type II (resistant), injection group 1: (Leishmania antigen plus booster dose at doses of $100-200 \mu \mathrm{g} / \mathrm{mL})(21-23)$. Another animal model study of cutaneous Leishmaniasis indicates that Th1 responses are essential for protection by vaccination and are usually predicated on the induction of high levels of IFN- $\gamma$ and low levels of IL-4, and this was confirmed by our results which show high $\|-12$ and low IL-10 in injection group (LBL) and Low IL-12 and high IL-10 in injection groups (LB) and (LT). This finding, also confirmed by recent studies, indicates that even vaccines triggering high levels of IFN- $\gamma$ do not protect in the presence of high levels of the regulatory cytokine IL-10 (34), and we observed the same results in this research: IL-12 has the highest level in the LBT group, whereas, the lowest levels belong to the LB group. IL-10 has the lowest level in the LBT group, but it is highest in the LB and LT groups (Table 1-3). It seems that II-4 and IL-12 have more light roles in post challenge protection. This research is a preliminary study on the new formulation of Leishmania major as vaccine and more studies are necessary in future.

\section{CONCLUSION}

Our results concluded that IL-12 has a direct correlation with the LBT group and conversecorrelation with IL-10. We consider that up regulation of Th1 cytokine (IL-12), and down regulation of Th2 cytokine (IL-10), have an essential role in cutaneous Leishmania disease and especially in protection with Leishmania vaccine.
Conflict of Interest: No conflict of interest was declared by the authors.

Financial Disclosure: The authors declared that this study has received no financial support.

Peer-review: Externally peer-reviewed.

Ethics Committiee Approval: Ethics committee approval was received from Tehran University Faculty of Medical Sciences.

Author Contributions: Concept - A.L.; Design - A.L.; Supervision - A.L., N.K.; Funding - Tehran University of Medical Sciences.; Materials - Faculty of Medicine, Dermal and Leprosy Center, Tehran University of Medical Sciences.; Data Collection and/or Processing - A.L., A.KH., M.J.G., Z.G.; Analysis and/or Interpretation - A.L., S.B.; Literature Review - A.L.; M.M.; Writing - A.L.; Critical Review - A.L., N.KH., M.J.G.

Acknowledgment: The authors would like to thank Farzan Institute for Research and Technology for the technical assistance, Akram Mir Amin Mohammadi from the Dermal and Leprosy Center of Tehran University of Medical Sciences for providing antigen and Reza Samani from the Department of Pathological Biology of Tehran University Veterinary Faculty for providing animal serum.

Çıkar Çatışması: Yazarlar çıkar çatışması bildirmemişlerdir

Finansal Destek: Yazarlar bu çalışma için finansal destek almadıklarını beyan etmişlerdir.

Hakem değerlendirmesi: Dış bağımsız.

Etik Komite Onayı: Bu çalışma için etik komite onayı Tehran Üniversitesi Sağlık Bilimleri Fakültesinden alınmıştır.

Yazar Katkıları: Fikir - A.L.; Tasarım - A.L.; Denetleme - A.L., N.K.; Kaynaklar Tehran University of Medical Sciences.; Materials Faculty of Medicine, Dermal and Leprosy Center, Tehran University of Medical Sciences.; Malzemeler - Faculty of Medicine, Dermal and Leprosy Center, Tehran University of Medical Sciences.; Veri toplanması ve/veya işlemesi - A.L., A.KH., M.J.G., Z.G.; Analiz ve/veya yorum - A.L., S.B.; Literatür taraması - A.L.; M.M.; Yazıyı yazan - A.L.; Eleştirel Inceleme - A.L., N.KH., M.J.G.

Teşekkür: Yazarlar Farzan Araştırma ve Teknoloji Enstitüsü'ne sağladıkları teknik yardım için, Tahran Tıp Bilimleri Üniversitesi Dermal ve Cüzzam Merkezi'nden Akram Mir Amin Mohammadi'ye antijen sağladığı için, Tahran Üniversitesi Veterinerlik Fakültesi Patolojik Biyoloji Bilim Dalı́ndan Reza Samani'ye hayvan serumu sağladığı için teşekkür eder.

\section{REFERENCES}

1. Cupolillo E, Medina-Acosta E, Noyes H, Momen H, Grimaldi G. Jr. A revised classificationfor Leishmania and Endotrypanum. Parasitology Today 2000; 16: 142-4. [CrossRef]

2. Robertson ID, Irwin PJ, Lymbery AJ, Thompson RC. The role of companionanimals in the emergence of parasitic zoonoses. International Journal for Parasitology 2000; 30: 1369-77. [CrossRef]

3. Ferreira WA, Mayrink W, dos Mares-Guia ML, Tavares CA. Detection and characterization of Leishmania antigens from an American cuta- 
neous Leishmaniasis vaccine for diagnosis of visceral Leishmaniasis. Diagn Microbiol Infect Dis 2003; 45: 35-43. [CrossRef]

4. Amaral VF, Teva A, Oliveira-Neto MP, Silva AJ, Pereira MS, Cupolillo $E$, et al. Study of safety, immunogenicity and efficacy of attenuated and killed Leishmania (Leishmania) major vaccines in a rhesus monkey (Macaca mulata) model of the human disease. Mem Inst Oswaldo Cruz 2002; 97: 1041-8. [CrossRef]

5. Sharifi I, Fekri AR, Aflation MR, Khamesipour A, Nadim A,Mousavi $M R$, et al. Randomized vaccine trial of single dose of killed Leishmania major plus BCG against anthroponotic cutaneous Leishmaniasis in Bam, Iran.Lancet 1998; 351: 1540-3. [CrossRef]

6. Selvapandian A, Duncan R, Debrabant A, Lee N, Sreenivas G, Salotra $P$, et al.Genetically modified live attenuated parasites as vaccines for Leishmaniasis. Indian J Med Res 2006; 123: 455-66.

7. Campos-Neto. What about Th1/Th2 in cutaneous Leishmaniasis vaccine discovery? Brazilian journal of Medical and Biological Research 2005; 38: 979-84. [CrossRef]

8. howard JG, Hale CE, Chan-liew WL. Immunuloical regulation of experimental cutaneous Leishmaniasis. I. Immunogenetics aspects of susceptibility to Leishmania tropica in mice. Parasite Immunol 1980; 303-14.

9. Guemonprez P, Valladeau L, Thery C, Amigorena S. Antigen presentation and $T$ cell stimulation by dendritic cells. Annu Rev Immunol 2002; 20: 621-67. [CrossRef]

10. Cella M, Scheidegger D, Palmer-Lehman k, Lane $\mathrm{p}$, Lanzavecchia A, Alber G. Ligation of CD40 and dendritic cells triggers production of high levels of interlukin -12 and enhances $T$ cell stimulatory capacity:T-T help via Apc activation. J Exp Med 1996; 184: 747-52. [CrossRef]

11. Qi H, Denning TL, Soong L. Differential induction of interlukin-10 and interlukin-12 in dendritic cells by microbial toll-like receptor activators and skewing of T- cell cytokine profiles. Infect Immun 2003; 71: 3337-42. [CrossRef]

12. Stober D, Schirmbeck R, Reiman J. IL-12/IL-18 dependent IFNgamma release by murine dendritic cells. J Immunol 2001; 167: 957-65.

13. Quinones M ,Ahuja SK, Melby PC, Pate L, Reddick RI, Ahuja SS. Performed membrane-associated stores of interlukin (IL)-12 are a previously unrecognized source of bioactive IL-12 that is mobilized within minutes of contact with an extracellular parasite. J Exp Med 2000; 192: 507-16. [CrossRef]

14. Kelsall BL,Biron CA,Shorma O, Kaye PM. Dendritic cells at the host -pathogen interface. Nat Immunol 2002; 3: 699-702. [CrossRef]

15. Goark PM, Engwerda CR, Kaye PM. Dendritic cells, but not macrophages, produce IL-12 immediately following Leishmania donovani infection. Eur J Immunol 1998; 28: 687-95. [CrossRef]

16. Ghalib HW, Whittle JA, Kubin M, Hasim FA, El-Hassan AM, Grabstein $\mathrm{KH}$. Interlukin -12 enhances Th1-type responses in human Leishmania donovani infections. J Immunol 1995; 154: 4623-9.

17. Locksley R M, Heinzl FP, Sadick MD, Holaday BJ, Gardner KD Jr. Murin cutaneous Leishmaniasis: susceptibility correlates with differential expantion of helper T cells subsets. Ann Inst Pasteur Immunol 1987; 138: 744-9. [CrossRef]

18. Lehman JG, Enssle KH, Lehmn I, Emenrfer A, Lomann Matthes ML. The capacityto produce IFN-gammarather than presenc of Intrlukin- 4 deernes the resistance and the degree of susceptibility to Leishmania donovani infection in mice. J Interferon Cytokine Res 2000; 20: 63-77. [CrossRef]
19. Moris L, Troutt AB, Met.cod KS, Kelso A. Handman E, Aebischer T. Interlukin-4 but not gamma-Interferon production correlates with the severity of murine cutaneous Leishmaniasis. Infet Immun 1993; 61: 3459-65.

20. Himmelrich $\mathrm{H}$, Launois $\mathrm{P}$, Maillard I, Beidermann T, Tacchini-Coittier F, Locksley RM, et al. InBalb/c mice IL-4 production during the initial phase of infection with Leishmania major is necessary and sufficient to instruct Th2 cell development resulting in progressive disease. J Immunol 2000; 164: 4819-25.

21. Latifinya A, Mohaghegh Hazrati S. Safety and Toxicity of a New Formulated Leishmania major Preliminary Vaccine in Animal Model Balb/c and Small White Conventional Laboratory Mice Türkiye Parazitol Derg 2008; 32: 103-8.

22. Latifyniaa A, Mohaghegh Hazrati S. Evaluation of the Effects of a New Formulation of Leishmania Major Antigen in Balb/C and Conventional White Laboratory Mice. J Microbiol Immunol Infect 2010; 43: 138-46. [CrossRef]

23. Latifynia A, Mohaghegh Hazrati S, Mahmodi M, Mohebali M. Study on immunity of Leishmania major new crude antigen as a vaccine against Leishmaniasis in out bred (resistant) and Balb/c (sensitive) mice. Archives of Razi Institute 2009; 64: 27-37.

24. Hondowicz BD, Scharton-Kersten TM, Jones DE, Scott P. Leishmania major-infected $\mathrm{CH} 3$ mice treated with anti -IL-12 mAb develop but do not maintain a Th2 response. J Immunol 1997; 159: 5024-31.

25. Park AY, Hondowicz BD, Scott P. IL-12 is required to maintain a Th1 response during Leishmania major infection. J Immunol 2000; 165 : 896-902.

26. Murray HW. Endogenous interlukine -12 regulates acquired resistance in experimental visceral Leishmaniasis .J Infect Dis 1997; 175: 1477-9. [CrossRef]

27. Himmelrich H,Parra-Lopez C, Tacchini-Cottier F, Louis JA, Launois P. The IL-4 rapidly produced in BALB/c mice after infection with Leishmania major down- regulatesIL-12 receptor beta2-chain expression on CD4+ T cells resulting ina state of unresponsiveness to IL-12.J Immunol 1998; 161: 156-63.

28. Mathur RK, Awasthi A, Wadhone P, Ramanamurtthy B, Saha B. Reciprocal CD40 signals through p38 MAPK and ERK-1/2induce countracting immune response. Nat Med 2004; 10 : 540-4. [CrossRef]

29. Roberts MT, Stober CB, McKenzie AN \& Blackwell JM. Interleukin-4 (IL-4) and IL-10 collude in vaccine failure for novel exacerbatory antigens in murine Leishmania major infection. Infection Immune 2005; 73: 7620-8. [CrossRef]

30. Scott P, Pearce E, Natovitz P\& Sher A. Vaccination against cutaneous Leishmaniasis in a murine model. II. Immunologic properties of protective and non-protective subfractions of soluble promastigote extract. J Immunol 1987; 139: 3118-25.

31. Lowry $\mathrm{OH}$, Rosebrough N, Farr AL, Randall RJ. Protein measurement with the folin phenol reagent. J Bio Chem 1951; 193: 265-75.

32. Shahraki MR, Arab MR, Mirimokaddam E, Palan MJ. The effect of Teucrium polium (Calpoureh) on liver function, serum lipids and glucose in diabetic male rats. Iran Biomed J 2007;11: 65-8. 